CHAPTER 19:

\title{
The Contribution of the IEA Civic and Citizenship Education Studies to Educational Research and Policy in Europe
}

\author{
Maria Magdalena Isac
}

\begin{abstract}
The main objective of this chapter is to describe the contribution of the IEA civic and citizenship education studies-Civic Education Study (CIVED) and International Civic and Citizenship Education Study (ICCS) - to educational research and policy in the European context during the last 20 years. To this end, the chapter begins by briefly introducing the major education research and policy priority areas regarding civic and citizenship education in Europe and provides a brief account of the participation of European countries in the IEA studies. Then, the contribution of IEA civic and citizenship education studies is illustrated by highlighting research themes, topics, and findings of specific prominence and relevance in Europe that were enabled by such data. Finally, there is a reflection on potential avenues for further research as well as for increasing the impact of the IEA studies in the European context.
\end{abstract}

\section{Introduction}

In 2007, I began my doctoral research in civic and citizenship education at the University of Groningen in the Netherlands as a researcher in the team responsible for coordinating the International Association for the Evaluation of Educational Achievement (IEA) International Civic and Citizenship Education Study (ICCS) 2009; I assisted in the preparation of the national reports. This endeavor introduced me to the world of the IEA international civic and citizenship education studies. Since then, I have been part of a vibrant international community of researchers working independently but enthusiastically on comparative research in civic and citizenship education making use of IEA data. Later I worked for the European Commission's Joint Research Centre, and I was involved in the coordination of the European Commission's participation in the ICCS 2016 study. Over these years, I have witnessed rapid development of the impact of the ICCS studies on the field of citizenship education in Europe and I am taking this opportunity to share my observations from my current vantage point on a university faculty.

In this chapter, I will illustrate how IEA civic and citizenship education studies (CIVED 1999, ICCS 2009, and ICCS 2016) stimulated a great deal of research connected to topics of interest for European educational policy. To this end, I begin by briefly describing the context and the main education research and policy priority areas regarding civic and citizenship education in Europe and show how the participation of European countries in IEA civic and citizenship studies was intertwined with growing interest in civic and citizenship education in Europe. Then, drawing on extant research findings, I highlight the main research themes that could be addressed by secondary analysis of IEA studies' data leading to findings that are informative for scholarly research, as well as for policy and practice of civic and citizenship education in the European context. Lastly, I reflect on opportunities for further research as well as for increasing the impact of the IEA studies in the European context.

Maria Magdalena Isac, KU Leuven, Leuven, Belgium and INVALSI (Istituto Nazionale per la Valutazione del Sistema dell'Istruzione), Rome, Italy

email: mariamagdalena.isac@gmail.com

(C) IEA International Association for the Evaluation of Educational Achievement 2021 


\section{The European Educational Policy Context and the IEA Civic and Citizenship Education Studies}

At the level of European education policy, civic and citizenship education has been the subject of growing attention over the last three decades. This interest was largely motivated by the collapse of Communism, growing concerns about the consequences of globalization and increased immigration (unwelcome in many countries), as well as by concern about anti-democratic and xenophobic movements. The need arose to address both "unity and diversity" in European societies along with declines in civic and political engagement among youth (especially in Western Europe). This led to attempts to understand how to prepare youth for living under democratic rule and in accordance with European values (especially but not exclusively in the post-communist European countries) (Barrett and Zani 2015; Campbell 2019; Knowles et al. 2018; Osler and Starkey 2006).

Many policy actions were taken to address these challenges. European institutions such as the European Union (EU) and international organizations such as the Council of Europe (CoE) have launched initiatives to promote social cohesion and active citizenship since the late 1970s (see also Osler and Starkey 2006; Print et al. 2002). These efforts have led to one particularly significant achievement of the EU educational policy: the provision of a common policy framework for European Member States in the field of civic and citizenship education. First, in 2006 social and civic competences were among the eight key competences identified by the European Parliament and the Council of the European Union as essential for European citizens of all ages. Second, in 2009, promoting equity, social cohesion, and active citizenship through school education was identified as one of the main objectives of the Strategic Framework for European Cooperation in Education and Training (ET 2020). These achievements provided European Member States with a common policy framework for coordinating their efforts in promoting and evaluating their policies in the field and opportunities for long-term planning. Indeed, these initiatives are currently being reinforced in the context of the new strategic framework for European cooperation in education and training 2030 (Council of the European Union 2021; European Council 2015; European Education and Training Expert Panel 2019).

These policy initiatives have provided an important context and motivation for the participation of European countries in the IEA civic and citizenship education studies. Indeed, a large number of European countries have been a prominent part of these IEA studies (CIVED 1999, ICCS 2009, ICCS 2016) from the start. For example, in CIVED 1999, there were 23 European educational systems out of the 28 participants (Torney-Purta et al. 2001); in ICCS 2009 the participating European educational systems were 26 out of a total of 38 (Schulz et al. 2010); and in ICCS 2016, there were 16 European out of 24 participants (Schulz et al. 2018) (see Figure 1). At the same time, as they were taking part in the international core of the ICCS study, the majority of participating European countries also administered the European questionnaires of ICCS 2009 and ICCS 2016 (see Kerr et al. 2010; Losito et al. 2018).

Findings and data from all IEA civic and citizenship education studies including the European modules of ICCS 2009 and 2016 were informative and often a source for EU education policy publications. Indeed, recurring topics of particular interest for those concerned with European education policy were the development of citizenship competences in all young people and promoting democratic school practices. The IEA studies also provided information on aspects of citizenship education policy such as curriculum organization and content, teaching and learning strategies, student assessment, school organization, relations between school and out-of-school contexts, and professional development for teachers. See, for example, Eurydice reports on civic and citizenship education (European Commission/EACEA/Eurydice 2017; Eurydice 2012). Moreover, data from the European modules provided a unique opportunity to focus on civic and citizenship education issues specific to Europe such as student knowledge about the European Union (EU) and its institutions, laws, and policies as well as student attitudes about issues such 
Figure 1: European countries by frequency of participation to IEA civic and citizenship education studies: CIVED 1999, ICCS 2009, ICCS 2016

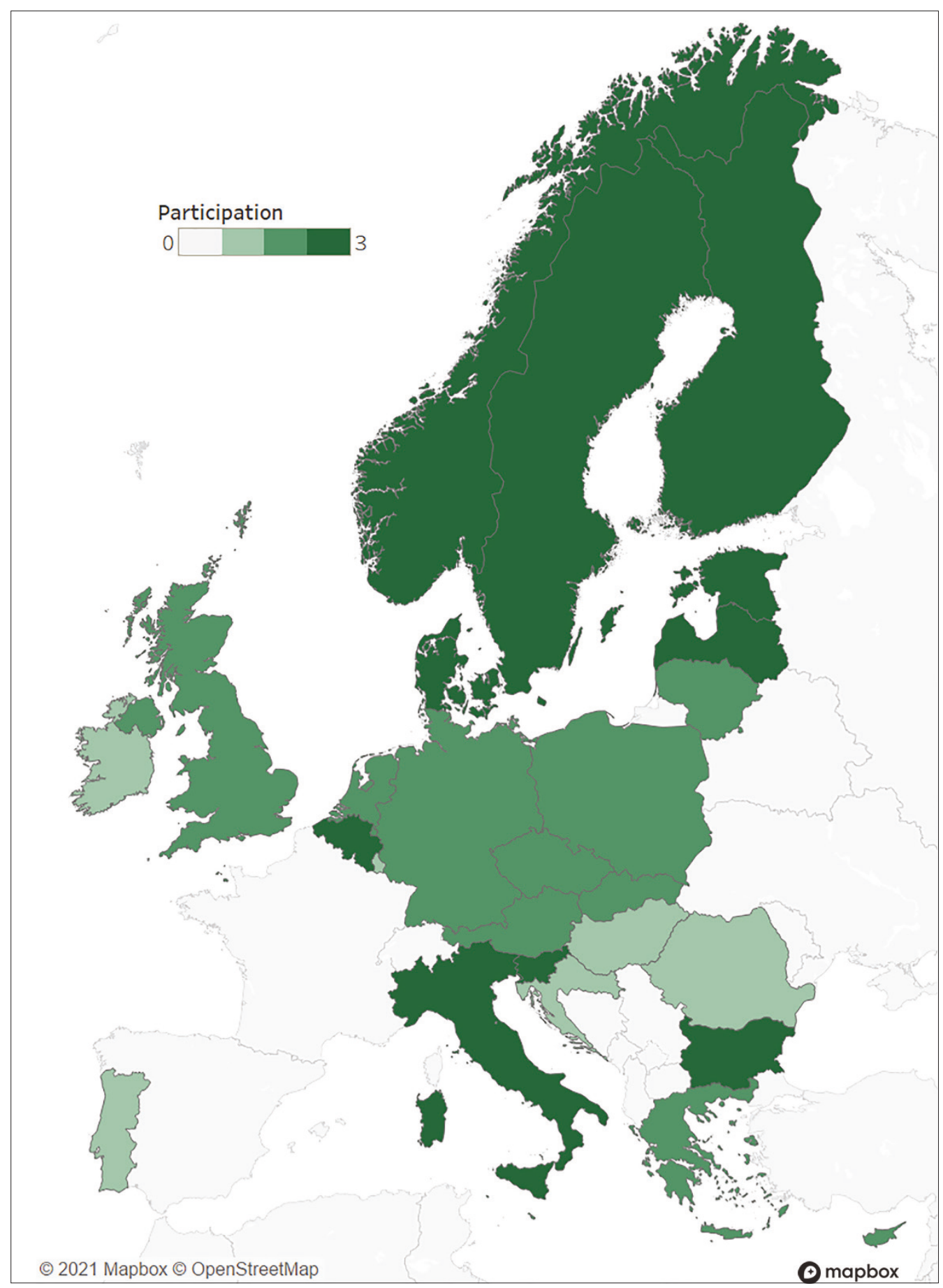

Source: Own elaboration based on participants in CIVED 1999, ICCS 2009, and ICCS 2016. See: https://www.iea.nl/index.php/ studies; The map was created using Mapbox and OpenStreetMap and their data sources. See: https://www.mapbox.com/about/ maps/ and http://www.openstreetmap.org/copyright

as European citizenship and identity, attitudes toward the free movement of citizens in Europe, attitudes toward the future of Europe, and the role of EU cooperation in addressing political and social problems. 
In recent years, themes discussed in the new strategic framework for European cooperation in education and training 2030, in a recent competency framework from the Council of Europe (Barrett et al. 2016), and in the research-based recommendations from the European Parliament (Veugelers et al. 2017) have highlighted several relevant topics. Secondary analysis of data collected by the IEA ICCS studies could be directed to these issues: developing media literacy and critical thinking, preventing radicalization in youth, preventing school violence, teaching common European values, promoting civic and intercultural competences, and encouraging practices of inclusion in schools (especially in this era of enhanced migration) (see also European Council 2015). A handbook chapter on civic education authored by three European researchers (Carretero et al. 2016) has provided suggestions about taking educational and social contexts into account in the examination of issues such as these.

\section{Established and Recent Themes in the European Research Landscape Making Use of IEA Civic and Citizenship Education Studies}

The educational policy initiatives and priority areas were accompanied by prolific empirical research on civic and citizenship education making use of IEA data. Indeed, the body of comparative research including European countries and based on data from the IEA civic and citizenship education studies has been growing considerably, sometimes with implicit connections to European issues. For example, a recent summary of research (Knowles et al. 2018) identified over 100 published articles reporting secondary analysis of CIVED 1999 and ICCS 2009 data. A large proportion of these publications are international comparative analyses that included several European countries, but some also report analyses focused on individual European countries. Most use data from the international instruments, and a few use data from the European regional module. A partially overlapping list of publications with a few more recent entries can be found at the website of the CivicLEADS Project (Regents of the University of Michigan 2020). Within and across countries groups of collaborating researchers are coalescing around common interests in the dataset as a whole.

The contents of these publications to a large extent address policymakers' needs for comparative data on outcomes and processes of citizenship education: understanding what appears to be successful in European school systems for the promotion of civic and citizenship competences (i.e., enhancing the knowledge of democracy, trust in democratic institutions, citizenship efficacy, civic engagement, acceptance of those who come from diverse backgrounds). Indeed, existing research, recently enriched by empirical articles reporting secondary analyses of ICCS 2016 data, falls largely into two categories: a) comparative studies focused on citizenship competences in youth, and b) comparative and country-specific studies focused on structural and learning approaches to citizenship education and their potential impact on youth citizenship competences.

In what follows, I give a brief overview of topics approached within these two research themes that have been addressed by secondary data analysis of IEA studies. Then, I point out some recent conceptual and methodological developments, which I illustrate by a few (by no means exhaustive) examples of empirical studies.

\section{Studies Focused on Citizenship Competences in Youth}

To give an overview, several studies using data from the IEA civic and citizenship education studies were dedicated to defining and then comparing citizenship competences in European youth. Reflecting both societal concerns and policy initiatives, some projects created composite or summary measures of citizenship competences (Hoskins et al. 2011). Some other studies focused on comparing attitudinal measures such as young people's institutional trust, voting intentions, and their attitudes toward support for immigrants' rights and gender equality (Barber and Ross 2018; Isac et al. 2019; Malak-Minkiewicz 2007; Miranda and Castillo 2018; Mirazchiyski et al. 2014; Torney-Purta and Barber 2011). Moreover, other research addressed comparisons of 
citizenship norms or perceptions of "good citizenship" behaviors among youth (Hooghe and Oser 2015; Hooghe et al. 2016). There has also been discussion and analysis of European identity and cosmopolitan attitudes (Keating 2016; Toots and Lauri 2015; Verhaegen et al. 2013).

In recent years, these analyses have addressed a number of conceptual and methodological topics. One of these is the increased concern about investigating and documenting the cross-cultural comparability of instruments measuring young people's endorsement of equal rights for different groups in society and the comparison of these attitudes across countries. Indeed, a number of recent publications based on CIVED 1999 and ICCS 2009 and 2016 data have been dedicated to understanding inter-European and international differences in young people's attitudes toward equal rights for immigrants, a topic of particular interest in the European context (Isac et al. 2019; Miranda and Castillo 2018; Munck et al. 2017). These studies demonstrated that it is important to assess cross-cultural comparability (or measurement invariance) when comparing attitudinal measures across countries and over time. The IEA studies focus considerable attention on the validity and comparability of measurement instruments, but cultural, linguistic, and geographic differences do exist and should be the explicit focus of secondary analysis of ICCS data (He and Van de Vijver 2013; Rutkowski and Svetina 2017). Here it is important to note that their findings indicated that European young people tend to be, on average, supportive of immigrants' rights. However, these attitudes show high variability within countries. For example, in ICCS 2016 Swedish students have both the highest average scores in Europe and the widest gap between the average scores of the students in the 5th and 95th percentile (see Isac et al. 2019).

Moreover, attitudinal differences are associated with individual characteristics such as the student's civic knowledge, socioeconomic status, immigration background, and gender. In particular, students of lower socioeconomic status, native-born students, students with lower levels of civic knowledge, and boys are less likely to endorse immigrants' rights (SandovalHernández et al. 2018).

In parallel, another topic and method of analysis has emerged in recent research. More specifically, in order to demonstrate the complexity of interconnections among attitudinal measures, some researchers have moved away from variable-centered analyses comparing group means to instead identify profiles of young people's attitudes using person-centered statistical approaches (Hooghe and Oser 2015; Hooghe et al. 2016; Reichert 2016; Reichert et al. 2018; Torney-Purta and Barber 2011). This approach applies in particular to the topic of young people's citizenship norms. For example, guided by Dalton's theoretical work and studies of adults on norms of civic duty (2008), researchers have used IEA data and employed latent class analysis to identify groups of students with different perceptions of "good citizenship" behaviors (Hooghe and Oser 2015; Hooghe et al. 2016). Consistent with Dalton's distinction, their results indicate that a large proportion of young people in a range of democracies (38 countries in ICCS 2009) express either "engaged citizenship" norms (highly endorsing the protection of human rights and community involvement, while downplaying the importance of traditional duty-based political participation) or "dutybased" citizenship norms (highly endorsing traditional political participation). Consistent with the findings of Hooghe et al. (2006), ongoing work with ICCS 2016 data (Treviño et al. 2021, in press) further confirms these findings by identifying five types or profiles of citizenship norms. These are comprehensive, socially engaged, duty-based, monitorial, and anomic. They find that across the European countries participating in ICCS 2016 large proportions of young people can be regarded as involved citizens who tend to hold holistic visions of good citizenship that are not limited to the fulfillment of duties but incorporate aspects of respect for the environment and human rights into their behaviors. 


\section{Studies Focused on the Role of Teaching and Learning Approaches and Structural School Characteristics in Citizenship Education}

Teaching and learning approaches to citizenship education and their association with student citizenship competences have become a prevalent theme in country-specific and comparative studies involving European countries and using IEA data. This research has particularly emphasized the important role of school environments in which high quality dialogue and debate on political and social issues are encouraged, where inclusive and mutually respectful teacher-student and student-student relationships are fostered and, where students are given opportunities to participate actively in extracurricular activities (e.g., volunteering in the community) as well as participating in the school's democratic structures.

Open classroom climate and its links to students' citizenship competences is one of the most frequently studied topics. A set of items measuring an open classroom climate-that is a classroom where participation and respectful discussion is encouraged-was first introduced in the IEA's civic education studies in the 1970s (Torney et al. 1975). Extensive analyses have provided evidence for the positive contribution of such classroom experience. Over time and contexts, this teaching and learning approach has been found to be positively related to a variety of citizenship competences in the European context and internationally. A number of cross-country and single country studies analyzed the role of open, participatory, and respectful discussion climate in European countries. These studies found an association between such a climate and several aspects of citizenship competence such as civic knowledge (Alivernini and Manganelli 2011; Isac et al. 2011), support for the norms of conventional and social-movement citizenship (Isac et al. 2014; Knowles and McCafferty-Wright 2015), political efficacy and political participation (Ekman and Zetterberg 2011; Quintelier and Hooghe 2013), and endorsement of equal rights for immigrants, ethnic minorities, and women (Isac et al. 2012; Sandoval-Hernández et al. 2018). This line of work can be linked to a seminal study reporting the analysis of the CIVED data within a group of European countries (i.e., Bulgaria, Czech Republic, Denmark, England, Germany, Italy, Norway, Sweden, and Switzerland) (Torney-Purta and Barber 2005). That study aimed to identify, by means of multiple regression analysis, school and teacher correlates of students' likelihood of voting as an adult and getting information about candidates before voting. The findings (largely confirmed by subsequent research with ICCS data) pointed to three aspects of schooling as relevant predictors in a majority of countries: students' reports of experiencing an open climate for classroom discussion, students' agreement that their participation makes a difference at their school, and students' membership on the student council.

Driven by interest in structural factors that could potentially be altered in order to provide more optimal conditions for civic and citizenship learning, some other studies focused specifically on the role of structural school characteristics such as average socioeconomic background of students, on the proportion of immigrants in the classroom/school, and on tracking in relation to student citizenship competences (Isac et al. 2012; Janmaat 2014; Kudrnáč and Lyons 2018; Sampermans 2019). These analyses have shown a consistently strong association between average (school) socioeconomic background and positive student outcomes such as civic knowledge, citizenship norms, political participation, and support for equal rights for immigrants, ethnic minorities, and women. They also indicated the importance of other contextual characteristics such as the proportion of immigrant students in the classroom. For example, Isac et al. (2012) showed that across a number of European countries participating in ICCS 2016, having a higher share of immigrant students in a classroom is positively related to native-born students' attitudes toward immigrants. Moreover, an analysis conducted by Sampermans (2019) also pointed to inequalities in citizenship competences within highly tracked educational systems such as the Netherlands or Flemish Belgium with students in the higher (general) educational tracks showing higher levels of civic knowledge in comparison to their peers enrolled in lower (vocational) tracks. 


\section{Recent Conceptual and Methodological Developments}

Recently, research focused on teaching and learning approaches to citizenship education and on structural school characteristics is making notable conceptual and methodological advances, which open up new research opportunities.

First, there is an increased interest in integrating several conceptual frameworks to simultaneously study concurrent explanatory mechanisms situated at different levels of analysis such as the student, the classroom, the school, and the educational system levels. The importance of this approach was recognized in a review of political socialization and civic education research by Torney-Purta et al. (2010). This research direction has been facilitated by methodological advancements such as multilevel modeling and structural equation modeling, which facilitate theory testing with a focus on multiple explanatory mechanisms situated at different levels (student, classroom, school, country). In addition, these substantive and methodological approaches have been used to examine interactions between factors situated at different levels (e.g., interactions between student background characteristics such as gender or socioeconomic background and aspects of class or school climate). Furthermore researchers have focused on several explanatory variables that can vary in their impact depending on school or country contexts.

Sandoval-Hernández et al. (2018), for example, used a framework rooted in ecological systems theory and educational effectiveness research to examine factors and conditions that have the potential to promote positive attitudes toward the rights of immigrants, ethnic groups, and women. This book-length report of analysis commissioned by IEA used data from 38 countries participating in ICCS 2009 (of which 26 were European). They examined the impact of several student and school characteristics on student attitudes. In five interconnected empirical analyses that acknowledged the complex, hierarchical layers of explanatory mechanisms, the authors reported in-depth on a particular topic and level of analysis (e.g., student background characteristics, teaching and learning practices in schools). These findings showed that several explanatory mechanisms are required to understand the factors that relate to young people's tolerant attitudes. The results suggested the importance of taking into account the dimensional structure of constructs (e.g., the strong positive association between attitudes toward immigrants, toward ethnic minorities, and toward women). The findings also pointed to the prominent role of background variables-singling out boys, low socioeconomic status students, and students with low interest in political and social issues, as the most likely to hold intolerant attitudes across countries. Moreover, the results showed once more the important role of democratic school cultures and climates that nurture open discussion and encourage free dialogue or critical debate. They identified a need for teacher professional development regarding the fostering of a classroom climate supportive of the teaching of potentially controversial issues.

Second, recent research gives attention to the ways in which students' ratings of the school environment are shaped by contextual school characteristics as well as by student background characteristics such as gender, being a migrant, or socioeconomic status (Barber et al. 2015; Claes et al. 2017; Reichert et al. 2018). For example, Reichert et al. (2018) used latent class analysis applied to ICCS 2009 data to investigate profiles of students' perceptions of their classroom and school environment (i.e., whether students have voice in school decisions and whether an open classroom climate prevails) in Northern European countries. They identified five distinct groups of students (i.e., alienated, indifferent, activist, debater, and communitarian) and found that aspects of the school environment were linked with these styles of participation. They found, for example, that compared to indifferent students, debaters, activists, and communitarians were more likely to be found in schools where teachers acted as role models by engaging in school governance. Moreover, Claes et al. (2017) used deliberative democratic theory to frame an analysis of how individual student characteristics influence an open climate for discussions 
in schools. Student gender as well as student socioeconomic status was found to be associated with students' perceptions of an open classroom climate for discussion. In particular, males and students who come from homes with a lower socioeconomic status appear to need additional encouragement to motivate them to actively participate in such learning environments.

Third, in addition to research focused on student perceptions, emerging research considers teachers' views of citizenship education, their beliefs, and their classroom practices (Reichert and Torney-Purta 2019; Reichert et al. 2020). This research makes use of the teacher data provided by the ICCS studies, which is collected from samples of teachers of all subjects. The data from the teachers is representative for each school and can be linked to school characteristics. However, due to the sampling design of ICCS studies, teacher data cannot be linked to individual students' data. Still, there is a long-standing interest in understanding the prevalence of certain teacher characteristics and practices, along with their contributions to positive citizenship outcomes for students. Therefore, even though studies using teacher data are rare and sometimes difficult to interpret, they make a contribution.

Specifically, Reichert and Torney-Purta (2019) applied latent class analysis to examine teachers' beliefs about the aims of civic and citizenship education in nine European countries (Eastern European, Nordic, and Western) and three Asian countries participating in the ICCS 2009 study. They found that a large majority of teachers prioritize learning aims that relate to the immediate learning context such as fostering students' participation in school settings and local communities as well as reducing everyday conflicts. Teachers across countries were unlikely to focus on encouraging students' future political participation. Instead, teachers in the Nordic countries and Slovenia believed it important to concentrate on promoting independent thinking and tolerance. The majority of teachers in England, Ireland, and Italy focused on transmitting civic knowledge and encouraging community participation. Teachers in Poland and the Czech Republic were more divided. A substantial group in each European country reported their goals as transmitting knowledge and encouraging community participation. Overall, however, within Europe there were substantial differences between countries in teachers' aims.

These findings highlight the challenges faced by teachers when organizing civic learning experiences. In particular, teachers appeared to avoid learning activities and goals that might require stating their own political views (which may be perceived as partisan). In addition to pointing out the importance of the impact that teachers' perception of their goals has on learning and teaching practices, this research also shows the influence of the national context in which civic and citizenship education takes place. More specifically, it appears that teachers in contexts in which democracy was seen to be under pressure at the time of testing (e.g., postCommunist countries) tended to focus on imparting civic knowledge and on participation in the local community. In contrast, teachers working in some long-standing democracies were likely to focus on independent thinking or inquiry-based approaches to promote social justice.

Fourth, a limited number of studies make use of the unique data from the European module of ICCS to focus on topics of special interest in the region such as opportunities for learning about Europe at school and their relevance for the development of European identity and cosmopolitan attitudes in young people (Keating 2016; Verhaegen et al. 2013). For example, Verhaegen et al. (2013) analyzed the data from 21 European Member States participating in the European Module of ICCS 2009 and used multilevel regression analysis to identify a positive association between cognitive and learning opportunities (i.e., acquiring information about social, political, and economic issues in other European countries; opportunities to interact with European peers) and young people's feelings of belonging to Europe and to the EU (i.e., European identity). They found a particularly strong association between cognitive learning opportunities (i.e., opportunities to learn about social, political, and economic issues in other European countries) and European identity. This finding was replicated and further enriched by the study of Keating 
(2016) that made use of the same dataset (for 20 EU countries) and established a link not only between specific learning opportunities and young people's European identity but also between these opportunities and their endorsement of equal rights for other European citizens. Both studies pointed out that student attitudes fundamental for European citizenship can benefit from learning experiences designed to foster knowledge of European issues and opportunities for contact and exchange with other Europeans. Such a line of research is promising and could be used to better understand the data from the ICCS European modules, which capture topics of unique relevance within Europe and the EU.

\section{Discussion and Conclusion}

This chapter has provided a short account of the contribution of the IEA civic and citizenship education studies (i.e., CIVED, ICCS) to educational research and policy in the European context. It began with a brief introduction to the main education policy priority areas regarding civic and citizenship education in Europe and provided a brief account of the participation of European countries in the IEA studies. Without aiming to be exhaustive, it highlighted some of the most common themes and topics that IEA data has allowed researchers to pursue with a focus on European educational systems. In this section, some suggestions for further research on civic and citizenship education in Europe are provided followed by a reflection on a series of potential actions that could increase the impact of the IEA studies in the European context.

\section{Opportunities for Further Research on Civic and Citizenship Education Topics with IEA Data in Europe}

The brief account of research findings from the analyses of CIVED and ICCS studies in this chapter demonstrates the importance of analyses of these data in the European context and the substantial advances that have been made in recent years suggesting topics that could be further addressed in future research.

First, the findings from a number of studies using CIVED and ICCS data from European countries show that considerable progress has been made in understanding the dimensions of citizenship competence. These include young people's institutional trust, voting intentions, and their attitudes toward support for immigrants' rights and gender equality. A considerable amount has been learned about teaching and learning approaches to citizenship education and their associations with students' competences. Advancements in these lines of research have been substantial and are characterized by an increased use of theory in an interdisciplinary fashion, methodological improvements (e.g., latent class analysis, multilevel analysis, structural equation modeling), a growing concern about contextual and individual differences in attitudes and in perceptions of learning environments (e.g., along the lines of school context, gender, immigration status, or socioeconomic status).

Prominent themes have been addressed in some research, such as the importance of open classroom climate and a sense of student empowerment at school. Investigations of these learning and teaching approaches in different contexts should be the subject of further investigation. Emerging themes such as individual student differences in perceptions of learning environments along the lines of gender, immigration status, and socioeconomic background are also important. They have the potential to provide information for tackling educational inequalities and designing learning environments tailored to students' needs. Moreover, additional insight into teachers' beliefs and classroom practices could be informative for teacher preparation in civic and citizenship education. Future studies, including ICCS 2022, could measure and gain deeper insight into how teachers view discussions of controversial issues in classrooms where there are diverse groups holding diverse opinions. It is also important to understand the beliefs that lie behind teachers' willingness or potential resistance in addressing such topics. European education policy and the preparation of teachers would benefit from such endeavors. 
Second, tremendous opportunities remain for future analysis of data that has been collected in this region. As noted earlier in this chapter, several themes are emerging both in European education policy as well as research. These include the need for media literacy and critical thinking about messages (especially in the digital world), preventing school violence, promoting intercultural competences, promoting a sense of inclusion in schools, and improving the initial and in-service learning activities for teachers of civic and citizenship education. Although European countries are collecting some of this information through the European questionnaire modules of ICCS, these data have received little attention in scholarly publications. World health issues will certainly receive enhanced attention in future studies.

Recent frameworks and data ${ }^{1}$ provided by the ICCS 2016 study offer opportunities with some new measurement instruments to explore these topics along with more established themes. Moreover, ICCS 2016 and especially the forthcoming ICCS 2022 studies are currently aligned with the UN's Sustainable Development Goals (SDG) (and particularly with education target 4.7). This will provide an opportunity for insights into other topics of relevance, such as issues related to global dimensions of citizenship education and education to enhance students' commitment to sustainable development (see Sandoval-Hernández et al. 2019; Sandoval-Hernández and Miranda 2018).

\section{Further Avenues for Increasing the Impact of the IEA Studies in the European Context}

Over time, European countries have been a prominent part of the IEA civic and citizenship education studies. Over the years and in all studies (CIVED 1999, ICCS 2009, and 2016), the number of participating European educational systems was the largest of any region in the world included in the studies (e.g., Latin America, Asia), and the development of the ICCS European Module provided additional opportunities to focus on topics of regional relevance. Yet, participation rates dropped in ICCS 2016 with a significant underrepresentation of countries from Eastern Europe. Lower participation rates are most likely the result of prioritizing different educational goals (e.g., the promotion of labor-market outcomes rather than citizenship competences) in relation to the resources and economic capacity of each educational system. The overall political climate has also been changing with the growing popularity of right-wing parties in some areas.

Looking at the use of CIVED and ICCS data for secondary analysis in the European context, we note a large and fruitful body of published research. It is apparent that some European research networks have been especially active in this field, and country-specific studies are also more common for a subset of educational systems (mainly Western and Northern European). Furthermore, the current overview of research findings suggests that there are relatively few empirical analyses of data from the European modules of ICCS in the published literature. However, one finds basic information in IEA reports (Kerr et al. 2010; Losito et al. 2018). The rise of authoritarian regimes and also corruption have been addressed mainly using data from the Latin American modules. Increased analyses of these data as well as European coverage of topics of worldwide interest could provide valuable comparative information regarding current challenges faced by many countries (and of successes as well). However, opportunities to collect new data may be challenged by increased polarization in Europe as well as by the pandemic.

More systematic efforts could be made to increase the impact of the ICCS studies in the European context. These initiatives might involve better connection between research with ICCS data and policy agendas and initiatives at international, European, and national levels. The need for

1 The IEA data, software, and training to analyze large-scale assessment data from Europe are freely available to researchers interested in conducting further analysis through the IEA archive (https://www.iea.nl/studies/iea/iccs), and the ILSA-Gateway (https://ilsa-gateway.org/). Another repository of these data and a list of existing publications using the data can be found in the archives of the University of Michigan's ICPSR in a project entitled CivicLEADS (https://www.icpsr.umich.edu/web/civicleads/series/202/data). 
enhanced preparation of teachers both prior to service and in service are widely recognized across countries. This an area where cross-European collaboration could be encouraged.

Furthermore, UNESCO's 2030 agenda for sustainable development and global citizenship education as well as the new strategic framework for European cooperation in education and training 2030 agenda in the field of inclusion and citizenship education could promote relevant research training and other opportunities. This is especially important in contexts in which there has been a drop in participation (e.g., Eastern European countries). Examining the chapters in the first part of this book that describe the meaning and utilization of findings in a number of European countries could provide suggestions for collaboration across the region. One might also focus on developing networks and partnerships that include researchers across disciplines together with those interested in enhancing teacher preparation. Although it is challenging in the current political climate, attention could be paid to making the findings relevant for a wider range of European countries and further consideration given to mechanisms for translating research findings into implications for policy and practice at the national and the regional levels.

While all these initiatives aim at better exploring the existing data, an alternative and potentially fruitful avenue would entail opening a dialogue with IEA project leaders about enriching the data collection process to oversample some populations that are currently underrepresented. Such an approach would be especially beneficial if it could provide data allowing responses to relevant policy issues. For example, the situation of migrant students is becoming an increasing concern in many European countries. At the moment the ICCS studies can offer only limited insights on such topics given the small proportion of migrant students in most countries' samples. The existence of a policy need for more information could trigger modifications that would allow oversampling these groups of students.

In summary, a large number of European educational systems have taken part in international studies of civic and citizenship education such as CIVED 1999, ICCS 2009, and ICCS 2016. Over two decades these studies as well as secondary analysis of their data have provided insightful and relevant findings for European citizenship education policy initiatives and practices. This chapter has highlighted some of the most relevant themes addressed in secondary analyses of these data and pointed out topics that could be further explored in future research.

\section{References}

Alivernini, F., \& Manganelli, S. (2011). Is there a relationship between openness in classroom discussion and students' knowledge in civic and citizenship education? Procedia-Social and Behavioral Sciences, 15, 3441-3445.

Barber, C., \& Ross, J. (2018). Cross-cohort changes in adolescents' civic attitudes from 1999 to 2009: An analysis of sixteen countries. Child Indicators Research, 11(2), 681-703.

Barber, C., Sweetwood, S. O., \& King, M. (2015). Creating classroom-level measures of citizenship education climate. Learning Environments Research, 18(2), 197-216. https://doi.org/10.1007/s10984015-9180-7

Carretero, M., Haste, H., \& Bermudez, A. (2016). Civic education. In Handbook of educational psychology (2nd edition) (pp. 295-308). New York, NY: Routledge/Taylor \& Francis Group.

Claes, E., Maurissen, L., Havermans, N., Hooghe, M., Jacobs, L., \& Claes, E. (2017). Let's talk politics: Which individual and classroom compositional characteristics matter in classroom discussions? International Journal of Press/Politics, 20(4_suppl), 395-414. https://doi.org/10.1177/1940161215596730

Council of the European Union. (2021). Council Resolution on a strategic framework for European cooperation in education and training towards the European Education Area and beyond (2021-2030). https://www.consilium.europa.eu/media/48584/st06289-re01-en21.pdf

Dalton, R. J. (2008). Citizenship norms and the expansion of political participation. Political Studies, 56(1). https://doi.org/10.1111/j.1467-9248.2007.00718.x 
Ekman, J., \& Zetterberg, P. (2011). Schools and democratic socialization: Assessing the impact of different educational settings on Swedish 14-year olds' political citizenship. Politics, Culture and Socialization, 2(2), 171-192.

European Commission. (2019). European Education and Training Expert Panel. Summary of findings and of the discussions at the 2019 Forum on the Future of Learning. Luxembourg: Publications Office of the European Union.

European Council. (2015). Declaration on Promoting citizenship and the common values of freedom, tolerance and non-discrimination through education. http://ec.europa.eu/dgs/education_culture/ repository/education/news/2015/documents/citizenship-education-declaration_en.pdf

Eurydice. (2012). Citizenship Education in Europe. Luxembourg: Publications Office of the European Union. Eurydice/European Commission/EACEA. (2019). Citizenship education at school in Europe - 2017. Eurydice report. Luxembourg: Publications Office of the European Union.

He, J., \& Van de Vijver, F. J. R. (2013). Methodological issues in cross-cultural studies in educational psychology. In G. A. D. Liem, \& A. B. I. Bernardo (Eds.), Advancing cross-cultural perspectives on educational psychology: A festschrift for Dennis Mclnerney (pp. 39-56). Charlotte, NC: Information Age Publishing.

Hooghe, M., \& Oser, J. (2015). The rise of engaged citizenship: The evolution of citizenship norms among adolescents in 21 countries between 1999 and 2009. International Journal of Comparative Sociology, 56(1), 29-52.

Hooghe, M., Oser, J., \& Marien, S. (2016). A comparative analysis of 'good citizenship': A latent class analysis of adolescents' citizenship norms in 38 countries. International Political Science Review, 37(1). https://doi.org/10.1177/0192512114541562

Hoskins, B. L., Barber, C., Van Nijlen, D., \& Villalba, E. (2011). Comparing civic competence among European youth: Composite and domain-specific indicators using IEA civic education study data. Comparative Education Review, 55(1), 82-110.

Isac, M. M., Maslowski, R., Creemers, B. P. M., \& van der Werf, M. P. C. (2014). The contribution of schooling to secondary-school students' citizenship outcomes across countries. School Effectiveness and School Improvement, 25(1), 29-63. https://doi.org/10.1080/09243453.2012.751035

Isac, M. M., Maslowski, R., \& van der Werf, M. P. C. (2011). Effective civic education: An educational effectiveness model for explaining students' civic knowledge. School Effectiveness and School Improvement, 22(3). https://doi.org/10.1080/09243453.2011.571542

Isac, M. M., Maslowski, R., \& van der Werf, M. P. C. (2012). Native students attitudes towards equal rights for immigrants. A study in 18 European countries. JSSE-Journal of Social Science Education, 11(1). https://doi.org/10.4119/jsse-586

Isac, M. M., Palmerio, L., \& van der Werf, M. P. C. (2019). Indicators of (in)tolerance toward immigrants among European youth: an assessment of measurement invariance in ICCS 2016. Large-Scale Assessments in Education, 7(1), 6. https://doi.org/10.1186/s40536-019-0074-5

Janmaat, J. G. (2014). Do ethnically mixed classrooms promote inclusive attitudes towards immigrants everywhere? A study among native adolescents in 14 countries. European Sociological Review, 30(6), 810-822.

Keating, A. (2016). Are cosmopolitan dispositions learned at home, at school, or through contact with others? Evidence from young people in Europe. Journal of Youth Studies, 19(3), 338-357. https://doi.org /10.1080/13676261.2015.1072617

Kerr, D., Sturman, L., Schulz, W., \& Burge, B. (2010). ICCS 2009 European report: Civic knowledge, attitudes, and engagement among lower secondary students in 24 European countries. Amsterdam, The Netherlands: International Association for the Evaluation of Educational Achievement.

Knowles, R. T., \& McCafferty-Wright, J. (2015). Connecting an open classroom climate to social movement citizenship: A study of 8th graders in Europe using IEA ICCS data. Journal of Social Studies Research, 39(4), 255-269. https://doi.org/10.1016/j.jssr.2015.03.002

Knowles, R. T., Torney-Purta, J., \& Barber, C. (2018). Enhancing citizenship learning with international comparative research: Analyses of IEA civic education datasets. Citizenship Teaching and Learning, 13(1), 7-30.

Kudrnáč, A., \& Lyons, P. (2018). Can political inequality be reduced in the classroom? Testing the compensation hypothesis and the BFLPE on youth civic competence. School Effectiveness and School Improvement, 29(2), 204-224. https://doi.org/10.1080/09243453.2017.1400444 
Losito, B., Agrusti, G., Damiani, V., \& Schulz, W. (2018). Young people's perceptions of Europe in a time of change: IEA International Civic and Citizenship Education Study 2016 European report. Amsterdam, the Netherlands: Springer.

Malak-Minkiewicz, B. (2007). Civic education in times of change: The post-communist countries. Citizenship Teaching and Learning, 3(2), 58-70.

Miranda, D., \& Castillo, J. C. (2018). Measurement model and invariance testing of scales measuring egalitarian values in ICCS 2009. In A. Sandoval-Hernández, M. M. Isac, \& D. Miranda (Eds.), Teaching tolerance in a globalized world (pp. 19-31). Amsterdam, the Netherlands: Springer.

Mirazchiyski, P., Caro, D. H., \& Sandoval-Hernández, A. (2014). Youth future civic participation in Europe: Differences between the East and the rest. Social Indicators Research, 115(3), 1031-1055.

Munck, I., Barber, C., \& Torney-Purta, J. (2017). Measurement invariance in comparing attitudes toward immigrants among youth across Europe in 1999 and 2009. Sociological Methods \& Research, 47(4), $687-728$.

Quintelier, E., \& Hooghe, M. (2013). The relationship between political participation intentions of adolescents and a participatory democratic climate at school in 35 countries. Oxford Review of Education, 39(5), 567-589.

Regents of the University of Michigan. (2020). CivicLEADS. https://www.icpsr.umich.edu/web/pages/ civicleads/index.html

Reichert, F. (2016). Students' perceptions of good citizenship: a person-centred approach. Social Psychology of Education, 19(3). https://doi.org/10.1007/s11218-016-9342-1

Reichert, F., Chen, J., \& Torney-Purta, J. (2018). Profiles of adolescents' perceptions of democratic classroom climate and students' influence: The effect of school and community contexts. Journal of Youth and Adolescence, 47(6). https://doi.org/10.1007/s10964-018-0831-8

Reichert, F., \& Torney-Purta, J. (2019). A cross-national comparison of teachers' beliefs about the aims of civic education in 12 countries: A person-centered analysis. Teaching and Teacher Education, 77, 112-125. https://doi.org/10.1016/j.tate.2018.09.005

Reichert, F., Torney-Purta, J., \& Liang, W. (2020). Teachers' organizational participation: Profiles in 12 countries and correlates in teaching-related practices. Theory \& Research in Social Education, 1-31. https:// doi.org/10.1080/00933104.2020.1795764

Rutkowski, L., \& Svetina, D. (2017). Measurement invariance in international surveys: Categorical indicators and fit measure performance. Applied Measurement in Education, 30(1), 39-51.

Sampermans, D. (2019). The democratic school climate: Active citizenship at school. KU Leuven. https:// lirias.kuleuven.be/retrieve/533466

Sandoval-Hernández, A., Isac, M. M., \& Miranda, D. (Eds.). (2018). Teaching tolerance in a globalized world. Cham, Switzerland: Springer.

Sandoval-Hernández, A., Isac, M. M., \& Miranda, D. (2019). Proposal of a measurement strategy for SDG Global Indicator 4.7.1 and Thematic Indicators 4.7. 4 and 4.7. 5 using international large-scale assessments in education. UNESCO Institute for Statistics. http://gaml.uis.unesco.org/wp-content/uploads/ sites/2/2019/08/GAML6-WD-7-Measuring-4.7.4-using-International-Large-Scale-Assessments-inEducation.pdf

Sandoval-Hernández, A., \& Miranda, D. (2018). Exploring ICCS 2016 to measure progress toward target 4.7. UNESCO. https://unesdoc.unesco.org/ark:/48223/pf0000266073

Schulz, W., Carstens, R., Losito, B., \& Fraillon, J. (2018). ICCS 2016 technical report. Amsterdam, the Netherlands: International Association for the Evaluation of Educational Achievement (IEA).

Schulz, W., Ainley, J., Fraillon, J., Kerr, D., \& Losito, B. (2010). ICCS 2009 international report: Civic knowledge, attitudes, and engagement among lower-secondary school students in 38 countries. Amsterdam, the Netherlands: International Association for the Evaluation of Educational Achievement (IEA). https://www. iea.nl/sites/default/files/2019-04/ICCS_2009_International_Report.pdf.

Toots, A., \& Lauri, T. (2015). Institutional and contextual factors of quality in civic and citizenship education: Exploring possibilities of qualitative comparative analysis. Comparative Education, 51(2), 247-275.

Torney-Purta, J., Amadeo, J.-A., \& Andolina, M. W. (2010). A conceptual framework and multimethod approach for research on political socialization and civic engagement. In L. R. Sherrod, J. Torney-Purta, \& C. A. Flanagan (Eds.), Handbook of research on civic engagement in youth. Hoboken, NJ: John Wiley \& Sons Inc. https://doi.org/10.1002/9780470767603.ch19 
Torney-Purta, J., \& Barber, C. (2005). Democratic school engagement and civic participation among European adolescents: analysis of data from the IEA Civic Education Study. Journal of Social Science Education. https://doi.org/10.4119/jsse-324

Torney-Purta, J., \& Barber, C. (2011). Fostering young people's support for participatory human rights through their developmental niches. American Journal of Orthopsychiatry, 81(4), 473.

Torney-Purta, J., Lehmann, R., Oswald, H., \& Schulz, W. (2001). Citizenship and education in twenty-eight countries. Delft, the Netherlands: International Association for the Evaluation of Educational Achievement (IEA). https://www.iea.nl/sites/default/files/2019-04/CIVED_Phase2_Age_Fourteen.pdf

Torney, J. V., Oppenheim, A. N., \& Farnen, R. F. (1975). Civic education in ten countries: An empirical study. Halstead.

Treviño, E., Carrasco, D., Claes, E., \& Kennedy, K. J. (Eds.). (2021, in press). Good citizenship around the world. Cham, Switzerland: Springer.

Verhaegen, S., Hooghe, M., \& Meeusen, C. (2013). Opportunities to learn about Europe at school. A comparative analysis among European adolescents in 21 European member states. Journal of Curriculum Studies, 45(6), 838-864

Open Access This chapter is licensed under the terms of the Creative Commons Attribution-NonCommercial 4.0 International License (http://creativecommons.org/licenses/by-nc/4.0/), which permits any noncommercial use, sharing, adaptation, distribution and reproduction in any medium or format, as long as you give appropriate credit to the original author(s) and the source, provide a link to the Creative Commons license and indicate if changes were made.

The images or other third party material in this chapter are included in the chapter's Creative Commons license, unless indicated otherwise in a credit line to the material. If material is not included in the chapter's Creative Commons license and your intended use is not permitted by statutory regulation or exceeds the permitted use, you will need to obtain permission directly from the copyright holder. 